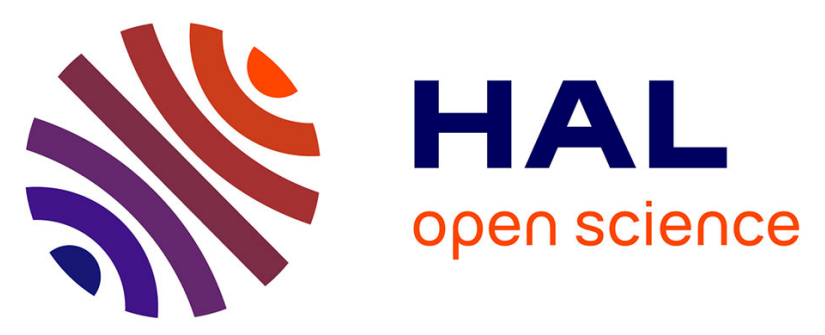

\title{
Structures of benthic prokaryotic communities and their hydrolytic enzyme activities resuspended from samples of intertidal mudflats: An experimental approach
}

Clarisse Mallet, Hélène Agogué, Frédérique Bonnemoy, Katell Guizien, Francis Orvain, Christine Dupuy

\section{To cite this version:}

Clarisse Mallet, Hélène Agogué, Frédérique Bonnemoy, Katell Guizien, Francis Orvain, et al.. Structures of benthic prokaryotic communities and their hydrolytic enzyme activities resuspended from samples of intertidal mudflats: An experimental approach. Journal of Sea Research (JSR), 2014, Trophic significance of microbial biofilm in tidal flats, 92, pp.158-169. 10.1016/j.seares.2014.01.005 . hal-01356084

\section{HAL Id: hal-01356084 \\ https://hal.science/hal-01356084}

Submitted on 24 Aug 2016

HAL is a multi-disciplinary open access archive for the deposit and dissemination of scientific research documents, whether they are published or not. The documents may come from teaching and research institutions in France or abroad, or from public or private research centers.
L'archive ouverte pluridisciplinaire HAL, est destinée au dépôt et à la diffusion de documents scientifiques de niveau recherche, publiés ou non, émanant des établissements d'enseignement et de recherche français ou étrangers, des laboratoires publics ou privés. 

resuspended from samples of intertidal mudflats: an experimental approach

3 Clarisse Mallet ${ }^{(1,2)^{*}}$, Hélène Agogué ${ }^{(3)}$, Frédérique Bonnemoy ${ }^{(1,2)}$, Katell Guizien ${ }^{(4)}$, Francis 4 Orvain $^{(5)}$, Christine Dupuy ${ }^{(3)}$.

(1) Clermont Université, Université Blaise Pascal, LMGE, F-63000 Clermont-Ferrand, 6 France.

7 (2) CNRS, UMR 6023, Laboratoire Microorganismes: Génome et Environnement, F-63177 8 Aubière, France.

(3) UMR 7266 CNRS - Laboratoire LIENSs, Université de La Rochelle, 2 rue Olympe de Gouges, 17000 La Rochelle, France.

(4) CNRS, Université Pierre et Marie Curie, UMR8222, LECOB, Observatoire

Océanologique, Avenue du Fontaulé, 66650, Banyuls/mer, France.

(5) Université de Caen Basse-Normandie, FRE3484 BioMEA CNRS, Esplanade de la Paix, 14032 Caen, France. +33473405375 .

\section{Abstract}

Resuspended sediment can increase plankton biomass and the growth of bacteria, thus influence the coastal planktonic microbial food web. But little is known about resuspension itself: is it a single massive change or a whole series of events and how does it affect the 
quantity and quality of resuspended prokaryotic cells? We simulated the sequential erosion of mud cores to better understand the fate and role of benthic prokaryotes resuspended in the water column. We analyzed the total, attached and free-living prokaryotic cells resuspended, their structure and the activities of their hydrolytic enzymes in terms of the biotic and abiotic factors that affect the composition of microphytobenthic biofilm.

Free living prokaryotes were resuspended during the fluff layer erosion phase (for shear velocities below $5 \mathrm{~cm} . \mathrm{s}^{-1}$ ) regardless of the bed sediment composition. At the higher shear velocities, resuspended prokaryotes were attached to particulate matter. Free and attached cells are thus unevenly distributed, scattered throughout the organic matter (OM) in the uppermost mm of the sediment. Only $10-27 \%$ of the total cells initially resuspended were living and most of the Bacteria were Cyanobacteria and Gamma-Proteobacteria; their numbers increased to over $30 \%$ in parallel with the hydrolytic enzyme activity at highest shear velocity. These conditions released prokaryotic cells having different functions that lie deep in the sediment; the most important of them are Archaea. Finally, composition of resuspended bacterial populations varied with resuspension intensity, and intense resuspension events boosted the microbial dynamics and enzyme activities in the bottom layers of sea water.

Key words: resuspension, mudflat biofilm, Bacteria, Archaea, community structure, hydrolytic activities

\section{Introduction}

Terrestrial and marine influences converge at tidal flats to produce a complex patchwork of habitats. Research on the productivity of coastal systems has established that intertidal flats influence, both physically and trophically, the adjacent marine and land areas. The intense microbial activity due to microalgae and prokaryotes in these areas results in great biological 
productivity that is essential for aquaculture. Mudflats are therefore socially and economically extremely important (Héral et al., 1989). Most of the primary production in these areas is due to benthic microalgae, mainly epipelic diatoms (Blanchard et al., 1998; Leguerrier et al., 2003) because the turbidity of the waters limits the presence of macrophytes and phytoplankton (McLusky, 1989). The twice-daily emersion in water and the access to daylight stimulates epipelic microalgae to migrate to the surface of the sediment, where they form a continuous biofilm. This biofilm may contain over $20 \mathrm{mg}$ of chlorophyll $(\mathrm{Chl} a)$ per $\mathrm{m}^{2}$ and its photosynthetic activity can increase the algal biomass, so doubling the size of the biofilm (Blanchard et al., 2002). This great productivity can lead to depletion of nitrogen or phosphorus, conditions that stimulate microalgae to secrete exopolymeric substances (EPS). These EPS are produced mainly by "overflow metabolism" or other processes like locomotion (Brouwer and Stal, 2002; Orvain et al., 2003). The EPS form a matrix around the microalgae (Paterson \& Black, 1999) that is one of the main resources leading to the rapid development of prokaryotes (Goto et al., 2001; Middelburg et al., 2000; van Duyl et al., 1999). Bacterial production can be as high as or even higher than the production of the microphytobenthos (Hamels et al., 2001; Pascal et al. 2009; Van Duyl et al., 1999). While the production of bacteria fluctuates widely during the year this does not result in fluctuations in their abundance. The poor correlation between biomass and bacterial production has been classically explained by their "top-down" disappearance (Thingstad, 2000). Several experiments designed to study grazing on mudflats (Brouage, France) (Pascal et al., 2009) throughout the year have shown that the bacteria consumed by larger animals never exceeded $6 \%$ of the bacterial production, so having only a limited impact on bacterial production and stock. However, grazers may stimulate bacterial production by disturbing the biofilm which allows the diffusion of oxygen and nutrients throughout the sediment (Alkemade et al., 1992) or by secreting nutrient-rich compounds such as mucus (Riemann and Helmke, 2002). The 
activity of grazers can also increase the resuspension of sediment leading to the export of benthic prokaryotes to the pelagic environment (Blanchard et al., 1997; Orvain et al., 2006). The free-living or particle-associated prokaryotes transferred to the water column may then find their way into coastal waters (Teal, 1962) where they may be consumed by filter-feeding organisms or pelagic grazers (Guizien et al., 2014; Wainright, 1987).

Both tidal currents and wind-induced waves can cause the resuspension of sediment (Blanchard et al., 2002). Sediment erosion generally increases with the rate of shear or friction $\left(\mathrm{u}^{*}\right.$ expressed in $\mathrm{cm} \mathrm{s}^{-1}$ ). Erosion rates depend on the balance between shear stress and the critical threshold for bed erosion. This threshold depends on properties of the sediment, and physical, geochemical and biological processes (Grabowski et al., 2011). The EPS matrix secreted by the benthic microbial communities plays a key role in sediment stabilization/destabilization, and hence in the export and retention of microphytobenthic and prokaryotic biomasses (Gerbersdorf et al., 2009; Underwood and Paterson, 2003). The sequential resuspension of microorganisms in a subtidal setting subjected to increasing hydrodynamics energy has been attributed to differences in sediment erodibility and the behaviour of microorganisms (Shimeta et al., 2003; Grabowski et al., 2011). This sequential resuspension of microorganisms should be enhanced during the erosion of the biofilms that form on the sediment surface in intertidal flats because the vertical structure of the biota is well defined. Chronic erosion (type 0 erosion) generally occurs and can be defined as a fluff layer erosion (i.e. simple detachment of loose aggregates from the sediment matrix, at low bed shear stress). Orvain et al. (2006) demonstrated the relevance of bioturbation by macrofauna in the creation of such a biogenic fluff layer. This chronic erosion can be followed by a catastrophic erosion (namely mass erosion; type I and/or II according to the consolidation status of the bed load), which corresponds to the general bed failure that can be achieved only when wind-induced waves produce high values of bed shear stress that can overpass the 
critical threshold for mass erosion (i.e. resistance force). This defined vertical distribution is accompanied by a spatial structure due to top-down control by benthic herbivores (Weerman et al., 2011). The drivers of sequential erosion and the critical erosion thresholds of the microorganisms that make up a biofilm are analyzed in a companion paper (Dupuy et al., this issue). Resuspension of the top few centimeters of sediment can increase the plankton biomass and bacterial growth (Wainright, 1990). This affects the coastal planktonic microbial food web due to the direct movement of cells from the sediment into the water column so increasing the seston concentration or the mineralizing capacity (Wainright, 1987; 1990). Dissolved nutrients and trophic interactions like bacterivory by nanoflagellates can also have indirect effects (Blanchard et al., 1997; Garstecki et al., 2002). Resuspension has been shown to increase the abundance and volume of bacteria in both field and experimental studies (Ritzrau and Graf, 1992; Wainright, 1987), but most of these early studies considered sediment resuspension to be a massive, homogeneous process. The present study resuspension experiments were done to determine whether the sequential resuspension of prokaryotes under varying environmental conditions could alter the direct and indirect effects on planktonic food-web. We monitored the enrichment of resuspended prokaryotic cells and their structure to assess if there was sequential resuspension under all the environmental conditions tested. We also checked whether prokaryotic cells were alive or dead so as to better identify their indirect effects on the plankton food-web. Lastly, we measured the activities of their hydrolytic enzymes. These enzymes regulate the assimilation of nutrient monomers by microbial cells and therefore play an important part in the cycling of organic matter and remineralization.

\section{Material and Methods}


Muddy sediment samples were collected from Marennes-Oléron Bay (Atlantic Coast of France) in July 2008 (Fig. 1) $\left(45^{\circ} 54^{\prime} 50^{\prime \prime} \mathrm{N}, 01^{\circ} 05^{\prime} 25^{\prime \prime} \mathrm{W}\right.$ ) during spring tides (17 and $19 \mathrm{July}$ ), maximum tides (21 July) and neap tides (22 and 24 July). At each sampling occasion, two 8 $\mathrm{cm}$ diameter sediment cores were taken at low tide (middle of the emerged period). Only ridges were sampled since biofilms are not normally found on runnels. The sediment cores were placed in a tank for transport back to the laboratory. The resuspension experiments were done at the time of the immersion period in the field. Three additional $15 \mathrm{~cm}$ diameter cores were taken to assess the biotic and abiotic parameters of the top $2 \mathrm{~cm}$ of sediment.

\section{$\underline{\text { Resuspension experiments and instrumentation }}$}

The sediment samples were transferred from the cylindrical cores to the bottom of the flume of an erosion device developed by IFREMER. This was modified to form a straight recirculation flume, named "Erodimetre" (Guizien et al., 2012; Le Hir et al., 2006; Orvain et al., 2007). The flume was filled with filtered artificial seawater (15L) to obtain a baseline close to 0 for each type of microorganism. The discharge through the erosion device was increased in twenty 5 -minute steps to yield bed friction velocities ranging from 0 to $11 \mathrm{~cm} \cdot \mathrm{s}^{-1}$. A total of 6 samples $(1.5 \mathrm{~L}$ each) were taken from the water column of the erodimeter as the flow, and thus shear velocity, was increased. These were used to monitor the resuspension of prokaryotes and the total particle matter (TPM) concentration. The induced bed shear stress was calculated from measurements of the pressure head loss between the upstream and downstream ends of the sample section (Guizien et al., 2012). Friction velocity was calculated as the square root of the bed shear stress divided by the sea water density. Turbidity and fluorescence were continuously recorded and used to measure chl $a$ and suspended particular matter. Erosion kinetics were analyzed to evaluate the relationship between bed erodibility 
147 (erosion rates of suspended particulate matter and chl $a$ biomass) and the sediment properties

148 (abiotic and biotic factors) and their temporal changes over 14 days (Orvain et al., this issue).

149 From this long set of experiments across a spring-neap tidal cycle, we selected 4 dates for a

150 detailed analysis of the fate of bacterial and archaeal benthic communities after resuspension.

151 The dates were chosen to evaluate the response of prokaryote resuspension for different

152 biofilm stages of development. The July 17 sample illustrated an increase in tidal range 153 (midtime between neap tides and spring tides, low tide occurs in the morning), those taken on 154 July 20 and 21 (spring tide) corresponded to a maximum tidal range (just before and just after 155 the peak, low tide occurred around noon), while the July 24 sample reflected the response to a 156 decrease in tidal range (midtime between spring tides and neap tides, low tide started after 157 noon).

\section{$\underline{\text { Abiotic parameters }}$}

Salinity and nutrient $\left(\mathrm{NH}_{4}, \mathrm{NO}_{3}, \mathrm{NO}_{2}, \mathrm{PO}_{4}\right.$, silicates) concentrations in the upper layer of the sediment

Pore water was separated from $300 \mathrm{~mL}$ of fresh sediment by centrifugation $\left(4{ }^{\circ} \mathrm{C}, 3000 \mathrm{~g}, 15\right.$ min). Several aliquots of interstitial water were obtained by passage through GF/C filters. Salinity was determined with a refractometer.

Ammonia was assayed using the colorimetric Koroleff (1969) technique immediately after filtration. The remainder of the filtered pore water was stored at $-20^{\circ} \mathrm{C}$. Nitrates, nitrites, silicates and phosphates were assayed using a Skalar automated segmented flow analyzer with classical spectrocolorimetric techniques (adapted from Treguer and Le Corre, 1975).

\section{Carbohydrates and proteins from EPS in the sediment}


EPS were extracted from $5 \mathrm{~mL}$ sediment as described in Takahashi et al. (2009). Bound EPS were extracted from pellets by suspending each one with about $1 \mathrm{~g}$ of cation exchange resin (Dowex Marathon $\mathrm{C}, \mathrm{Na}+$; Sigma-Aldrich) and $5 \mathrm{~mL}$ ASW and gently agitating the suspension for $1 \mathrm{~h}$ at $4^{\circ} \mathrm{C}$. The samples were then centrifuged $\left(15^{\circ} \mathrm{C}, 3000 \mathrm{~g}, 10 \mathrm{~min}\right)$ and the resulting supernatants were frozen $\left(-20^{\circ} \mathrm{C}\right)$. Aliquots $(1 \mathrm{~mL})$ of each fraction were used to measure the carbohydrate contents by the Dubois method (Dubois et al., 1956) with Dglucose (Sigma-Aldrich) as a standard.

\section{Total particulate matter (TPM): particulate organic (POM) and mineral (PIM) matter}

TPM was measured according to Aminot and Chaussepied (1983). Erodimeter seawater samples $(100-500 \mathrm{ml})$ were filtered through a Whatman GF/C (47 $\mathrm{mm}$ in diameter) under reduced pressure $<10 \mathrm{~mm} \mathrm{Hg}$ within $1 \mathrm{~h}$ after the end of the experiment. Each filter was heated at $490^{\circ} \mathrm{C}$ for $2 \mathrm{~h}$ to eliminate any organic carbon matter and weighed. Filters that had been used to treat samples were rinsed twice with distilled water to remove salt, dried at $60^{\circ} \mathrm{C}$ for $12 \mathrm{~h}$ and weighed to measure the TPM. The proportions of particulate inorganic matter (PIM) and particulate organic matter (POM) were determined by heating the filters at $490^{\circ} \mathrm{C}$ for $2 \mathrm{~h}$ and then weighing them.

Another $40 \mathrm{~mL}$ sample of sediment was stored frozen $\left(-20^{\circ} \mathrm{C}\right)$ and freeze-dried for estimation of $\mathrm{C}$ and $\mathrm{N}$ using a nitrogen and carbon analyser 1500 (CARLO ERBA).

\section{$\underline{\text { Biotic parameters }}$}

The algal biomass in sediment and water was assessed using chlorophyll $a$ as a proxy, which was measured fluorometrically (Lorenzen, 1966).

Benthic prokaryotes were extracted from the sediment as recommended by Danovaro et al. (2001) and Manini and Danovaro (2006) and each sample was divided into two aliquots. One 
was fixed with $(1 \%)$ glutaraldehyde and stored at $4{ }^{\circ} \mathrm{C}$. The other was stored at $4{ }^{\circ} \mathrm{C}$ and used to detect "live" and "dead" cells. Prokaryotes were counted in a FACSCalibur flow cytometer (Becton Dickinson) equipped with an air-cooled laser providing $15 \mathrm{~mW}$ at $488 \mathrm{~nm}$ with the standard filter set-up. Samples were stained with SYBR Green 1 (1:10X, 10,000 fold dilution of commercial stock, Molecular Probes, Oregon, USA) (Brussaard, 2004; Duhamel and Jacquet, 2006). Populations of prokaryotes differing in size and fluorescence intensity were identified by plotting side scatter (SSC) against green fluorescence (530 nm wave- length, fluorescence channel 1 of the instrument, FL1). We also identified free and particle-associated prokaryotes (attached cells). The live and dead cells in unfixed samples were measured in samples that had been diluted and stained with SYBR Green $1(1: 10 \mathrm{X})$ and $10 \mu \mathrm{g} \mathrm{ml} \mathrm{m}^{-1}$ propidium iodide (Sigma Chemical Co.), and incubated for $15 \mathrm{~min}$ in the dark at room temperature (Falcioni et al., 2008). A dot plot of red (670 nm fluorescence channel 3, FL3) against green fluorescence (FL1) distinguished live cell clusters (cells with intact membranes and DNA) from dead cells (with compromised membranes). FCM list modes were analysed using CellQuest Pro software (BD Biosciences, version 4.0).

The efficiency with which cells were transferred to the erodimeter water during the erosion was calculated from the enrichment factor $(\mathrm{EF})$ :

\section{$E F=\frac{\text { Water Cell concentration }}{\text { TPM }} /$ Sediment cell content}

Where the water cell concentration is in cell. $\mathrm{mL}^{-1}, \mathrm{TPM}$ is in $\mathrm{mg} \cdot \mathrm{mL}^{-1}$, and the cell content of the $1^{\text {st }} \mathrm{cm}$ of sediment core is in cell. $\mathrm{mg}^{-1}$ dry sediment.

\section{Potential enzymatic activities}


The potential $\beta$-glucosidase and leucine aminopeptidase activities in sediment were measured essentially as described by Mallet and Debroas (1999, 2001). The saturating concentrations of methylumbelliferone (MUF)- $\beta-$ D-glucoside used for the sediment and the water samples were the same: $1 \mathrm{mM}$ for $\beta$-glucosidase activity and $100 \mu \mathrm{M}$ of L-leucine-7-amino-4$\beta$ naphthylamide for leucine aminopeptidase activity. Controls and triplicate sediment samples were incubated at in situ temperature for 45,75 and 120 min to measure $\beta$-glucosidase activity and for 10, 30 and 60 min to measure leucine aminopeptidase activity. Water samples were incubated with substrate for $24 \mathrm{~h}$ to measure $\beta$-glucosidase activity and for $6 \mathrm{~h}$ to measure leucine aminopeptidase activity. The fluorescence of the supernatants $\left(14000 \mathrm{~g}\right.$ at $4^{\circ} \mathrm{C}$ for 2 min) were also measured (SAFAS FLXXenius spectrofluorimeter) using excitation at $365 \mathrm{~nm}$ and emission at $460 \mathrm{~nm}$ for $\beta$-glucosidase activity and excitation at $340 \mathrm{~nm}$ and emission at $410 \mathrm{~nm}$ for aminopeptidase activity. Solutions of 4-methylumbelliferone $(0-1 \mu \mathrm{M})$ for $\beta$ glucosidase activity and 2-naphthylamine $(0-12.5 \mu \mathrm{M})$ for aminopeptidase activity were freshly prepared with sediment slurry and used as standards. Specific activities were also calculated by dividing the total fluorescent by the total cell concentration (nmol.cell ${ }^{-1} \cdot \mathrm{h}^{-1}$ ).

\section{Prokaryotic genetic structure}

Genomic DNA was extracted from fresh sediment (equivalent of $650 \mathrm{mg}$ oven-dried sediment) and purified using the Ultra Clean Soil DNA isolation kit (MoBio Laboratories) according to the manufacturer's instructions. Genomic DNA was extracted from water onto $0.2 \mu \mathrm{m}$ filter (100 mL) and purified by alkaline lysis (Batisson et al., 2009). DNA quality was checked by electrophoresis on $1 \%(\mathrm{w} / \mathrm{v})$ agarose gels and quantified using NanoDrop.

The bacterial (V6-V8 regions) and archaeal 16S rDNA genes were amplified by PCR using the primers GC-968f and 1401r for bacterial DNA and GC-934f and 1386r for archaeal DNA (MWG-Biotech). The PCR mix $(50 \mu \mathrm{L})$ contained $1 \mathrm{X}$ PCR buffer, $2.5 \mathrm{mM} \mathrm{MgCl} 2,200 \mathrm{mM}$ 
of each dNTP, $20 \mathrm{pmol}$ of each primer, $250 \mathrm{ng} \mathrm{mL}^{-1}$ bovine serum albumin (BSA, Sigma), 1.5 units of HotStart Taq DNA polymerase (Qiagen), and 30 ng sediment DNA extract. The samples were amplified in an iCycler thermocycler (Bio-Rad) using the following programs: for bacteria: $15 \mathrm{~min}$ at $95^{\circ} \mathrm{C}, 35$ cycles of $1 \mathrm{~min}$ at $97^{\circ} \mathrm{C}, 1 \mathrm{~min}$ at $58^{\circ} \mathrm{C}$ and $1 \mathrm{~min}$ at $72^{\circ} \mathrm{C}$, and finally $10 \mathrm{~min}$ at $72^{\circ} \mathrm{C}$; for archaea: $15 \mathrm{~min}$ at $95^{\circ} \mathrm{C}$ for, 14 cycles of $45 \mathrm{~s}$ at $95^{\circ} \mathrm{C}$, for $1 \mathrm{~min}$ at $65^{\circ} \mathrm{C}$ decreasing to $58.5^{\circ} \mathrm{C}$ in $0.5^{\circ} \mathrm{C}$ steps at each cycle, and $30 \mathrm{~s}$ at $72^{\circ} \mathrm{C}$ then 20 cycles of $45 \mathrm{~s}$ at $95^{\circ} \mathrm{C}, 1 \mathrm{~min}$ at $58^{\circ} \mathrm{C}$ and $30 \mathrm{~s}$ at $72^{\circ} \mathrm{C}$, and finally $7 \mathrm{~min}$ at $72^{\circ} \mathrm{C}$. PCR products were checked by electrophoresis through $0.8 \%(\mathrm{w} / \mathrm{v})$ agarose gels and quantified using the DNA quantitation kit fluorescence assay (Sigma). PCR-16S rDNA gene products were analysed by DGGE using a D-Code Universal Mutation Detection System (Bio-Rad). Aliquots of each PCR product (500 ng) were loaded onto $8 \%$ polyacrylamide (w/v) denaturating gels with linear gradients of 40-60\% (100\% denaturant contains $7 \mathrm{M}$ urea and 40\% formamide). Gels in 1X TAE buffer ( $\mathrm{pH} 8$ ) were subject to $70 \mathrm{~V}$ at $60^{\circ} \mathrm{C}$ for $16 \mathrm{~h}$. The DGGE gels were then stained in 1X TAE buffer containing Gel Star diluted 1/20000 (Lonza, Rockland, ME-USA) and the band patterns digitized using a BioSpectrumAC Imaging System (UVP). The digital data were analysed using Gel ComparII software (Applied Maths, Kortrijk, Belgium). The total band intensity of each lane was normalised among lanes and used to calculate the relative abundance of each major OTUs (\%). A DNA band was considered to significant if it accounted for more than $0.5 \%$ of the total lane intensity. The richness $(R)$ was estimated as the number of bands. The richest samples were cloned and sequenced. The genomic DNA in these samples was amplified with 968f/1401r or 934f/1386r primers and cloned into a pGEMT-Easy vector (Promega) to construct clone libraries. These clones were reamplified and rerun on DGGE gels to compare them with the parent bands. At least two cloned fragments that comigrated with the original bands were sequenced (MWG - Biotech). Sequences were submitted to the National Center for Biotechnology Information (NCBI, BLASTn program 
(Altschul et al., 1997) for species assignment and to the CHECK-CHIMERA program of the Ribosomal Database Project (RDP (Maidak et al., 1999)) to detect potential chimeric artifacts (Kopczynski et al., 1994).

\section{$\underline{\text { Statistical analyses }}$}

Statistical analyses were carried out using PAST software (PAlaeontological STatistics, Hammer et al., 2001). Principal component analysis (PCA) was used to group samples according to environmental variables using the Pearson correlation coefficient. Prior to use one-way analysis of variance (ANOVA), to test difference between sediment cores for a given parameter, normality and homoskedasticity were checked (Shapiro-Wilk test and Levene's test respectively). Differences between individual means were then compared using Tükey’s honest significant difference (HSD) post-hoc test. Significance was set at $\mathrm{p} \leq 0.05$. Correlations between abiotic parameters and chlorophyll $a$ contents, enzymatic activities and prokaryotic abundances in erodimeter water were checked with the Pearson correlation coefficient (r) and its statistical significance. Pairwise similarity matrices were calculated for the DGGE patterns using the Dice equation for presence/absence and the Bray-Curtis equation for relative peak height data. Dendrograms were generated from the Dice matrix as described by Ward (1963). The consistency of a cluster was described by the cophenetic correlation, which calculates the correlation between the dendrogram-derived similarities and the matrix similarities. Pairwise Analysis of Similarity (ANOSIM, Clarke and Warwick, 2001) was used to test if the sediment samples were similar in term of chemical and biological parameters. It tested the hypothesis that parameters within each sediment sample were more similar to each other than to parameters in the other samples. The statistical significance of the separation was given by a Bonferroni-corrected $p$-value $(\mathrm{R}, p<0.05)$. 


\section{Sediment}

292

The biological and chemical parameters of the sediment cores taken at different dates were significantly different (R: 0.55 p: 0.0001, Fig. 2). The July 17 cores were opposite to the other samples (Fig. 2) with significant lowest salinity (Table 1), which implied the highest water content. This date was also characterized by significant lower colloidal carbohydrate concentrations than those of the July 21 and 22 (Table 1). The July 22 samples were also significantly differed to the other sampling dates (Fig. 2) with silica concentrations significantly lower than the other (Table 1). The profiles of the core samples taken on this date seemed to be opposite to those of the July 21 and 24 samples, whose sediments had the highest nitrogen concentrations (Fig. 2; Table 1). The highest prokaryotic abundances were observed in the July 17 and 24 samples (Table 1). For the July 17 and 22 samples, highest leucine aminopeptidase activities were observed with for the July 22 sample highest $\beta$ glucosidase activity too (Table 1$)$.

The structures of the bacterial communities in the four sediment samples differed significantly (R: 0.9, p: 0.008). We found only 3 major phyla: Gamma-Proteobacteria (mainly Pseudomonadales and Chromatiales and unidentified Gamma-Proteobacteria), Actinobacteria and Cyanobacteria (Fig. 3A). The richness (as numbers of DGGE bands) varied from 22 on July 24 to 33 on July 21 (Fig. 3A). Crenarchaeota formed the major group except in the July 17 samples (Fig. 3B). The July 22 cores were the least rich (14) and the July 17 cores were the richest (33). 
We gradually increased the shear velocity $\left(u^{*}\right)$ in the erosion flume to mimic low to highly

313 turbulent flow. There were two phases of total particulate matter (TPM) erosion. The shear velocity in the first phase was low $\left(\mathrm{u}^{*}<5 \mathrm{~cm} \cdot \mathrm{s}^{-1}\right)$ and the concentration of particles was very low. Only the biogenic fluff layer was resuspended during this phase. This layer is mostly composed of particles detached from the sediment matrix like the fluff layer or track and/or pseudofecal mounds created by faunal bioturbation). In the second phase mass erosion of the sediment occurred and the number of particles increased (Orvain et al., this issue).

Enrichments of resuspended prokaryotes (total cell fraction) was more effective with velocities below $5 \mathrm{~cm} \cdot \mathrm{s}^{-1}$, before and during the precocious erosion phase, when the biogenic fluff layer was resuspended, as this layer is created by surface fauna activity like tracks (Fig. 4A). The total cell abundance in the erosion flume fluctuated little, from $1.310^{5}$ cells. $\mathrm{ml}^{-1}$ on July 17 and $3.610^{5}$ cells. $\mathrm{ml}^{-1}$ on July 22 under our controlled conditions. The enrichment in free cells followed the same pattern as that for total prokaryotes (Fig. 4A) and represented $75.1 \pm 16.5 \%$ of total resuspended cells. Enrichment at the lowest friction was maximal on July 17 and decreased as erosion increased. There was little enrichment in attached cells but it increased during resuspension of the biogenic fluff layer (Fig. 4B). The concentration of attached cells increased when there was mass erosion of the sediment and enrichment reached $25 \%$ on July 24 and $44 \%$ on July 21 . Less than a third of the cells in the erodimeter water were intact (potentially active). Their enrichments followed the same pattern as that of the

331 free cells but there were fewer of them (Fig. 4C). They accounted for only $10 \%$ of the total cells on July 17 and $27 \%$ on July 21 , but their abundance increased to more than $30 \%$ of the

333 total cells at the end of the experiment, during sediment mass erosion. The $\beta$-glucosidase 334 activity fluctuated between $2.410^{-7}$ and $1.910^{-6} \mathrm{nmol}^{-c e l l^{-1}} \mathrm{~h}^{-1}$ and that of leucine335 aminopeptidase between $6.510^{-7}$ and $4.410^{-6} \mathrm{nmol} \mathrm{cell}^{-1} \mathrm{~h}^{-1}$. The activities had lowest values 
when the shear velocity was less than $5 \mathrm{~cm} \cdot \mathrm{s}^{-1}$, except for the samples collected on July 21 and July 24 (Fig. 5A, B).

The PCA map indicated that the enrichments in total, free and live cells varied inversely as enrichment in total particulate matter, chlorophyll $a$ and the enzyme activities (Fig. 6). The other axis was better characterized by the $\mathrm{C}: \mathrm{N}$ ratio and the concentration of attached cells. These two axes clearly separated the samples into two major clusters (Fig. 6). The samples corresponding to mass erosion of sediment, rich in TPM lay on the first axis. Conversely, the samples corresponding to erosion of the biogenic layer lay on the second.

\section{Structure of resuspended prokaryotes}

Attached cells accounted for more of the resuspended bacteria than did free cells for all dates (Fig. 7). Bacterial populations were resuspended sequentially, especially for the July 17 and July 24 samples, Gamma-proteobacteria and Pseudomonales appeared first, followed by Actinobacteria and finally the Chromatiales (Fig. 7A) and the Cyanobacteria (Fig. 7E), which were also resuspended at the beginning of the experiment. Nevertheless, enrichment varied with the sampling date both qualitatively (OTUs) and quantitatively (relative abundance of each OTU). Concerning the archaeal community, Archaea were only detected during the mass erosion events. The dominant Archaea were crenarchaeotal populations (mainly unidentified Crenarchaeota, MG I and thermoprotei) (Fig. 8). Archaeal cells were very effectively resuspended, except from the July 17 sample, because the richnesses in the resuspended fractions were greater than those of the sediment. The mass erosion of sediment collected on July 17 produced the greatest richness and diversity and there was a sequential appearance of populations, as for the Bacteria (Fig.8).

\section{Discussion}


It has been claimed that erosion of the sediment bed affects the pelagic trophic network by inhibiting primary production because it increases turbidity. But it may also be affected directly or indirectly by active prokaryotes released from the sediment. We have characterised the sequential release of prokaryotes from bed sediment samples in terms of their structure (free or attached cells and their composition), physiology (alive or dead) and enzyme activity that were resuspended by increasing erosive forces from samples with and without biofilm.

\section{Resuspension of prokaryotic cells}

Subtidal sediments remain unconsolidated and are relatively easy to erode. But sediment in intertidal areas exposed to the air tends to become consolidated after recurrent desiccation and biofilm development (De Brouwer and Stal, 2001; Orvain et al., 2007; Porter et al. 2010; Underwood and Paterson, 2003). The sediment samples we studied were very resistant to erosion. Mass erosion was produced only by high shear velocities $\left(\mathrm{u}^{*}>5 \mathrm{~cm} \cdot \mathrm{s}^{-1}\right)$. These shear velocities can only be generated by wind-induced waves in the field. This tendency held for all sediments, despite differences in their chemical characteristics. Very low shear velocities resulted in limited erosion of the TPM in all our experiments. The intensity of this 'fluff layer erosion' varied with the composition of the bed sediment and the critical threshold shear velocity (Dupuy et al., this issue; Orvain et al., this issue).

Prokaryotes were always resuspended during the fluff layer erosion phase when shear velocities were below $5 \mathrm{~cm} . \mathrm{s}^{-1}$ and before the great increase in particulate matter erosion at higher shear velocities. Low friction velocities, when the concentrations of TPM were low, produced the greatest enrichment in prokaryotic cells. Enrichment decreased at the end of the fluff layer erosion when mass erosion began. The fluff layer in a mud site can be very important for sediment transport (Orvain et al., 2007; Ziervogel et al., 2006), because this material is especially enriched in $\mathrm{OM}$ and constitute a chronic erosion compared to the 
general bed failure, which can be defined as 'catastrophic' (Mariotti and Fagherazzi, 2012). The unconsolidated surface fluff layer, with a water content close to $85-98 \%$ of dry weight, was resuspended using low hydrodynamic conditions. The cells were unevenly distributed; they are scattered throughout the top $\mathrm{mm}$ of the sediment in the organic matter and this distribution is probably due to the patchy distribution of microphytobenthic biofilms (Dupuy et al., this issue). The surface layers of sediment always contained more bacteria than did the subsurface suboxic sediment layers (Parkes et al., 2000). The decrease in microbial cell counts down through the sediment profile and the shift in community structure probably results from the decreased in organic carbon quality and availability in aged, deeply buried sediments (Parkes et al., 2000). The volume of pore-water may also be a major determinant of prokaryotic abundance in sediments (Schmidt et al., 1998). The force that determines the decrease in prokaryotic abundance and changes in community structure down the vertical profile of a sediment can be a complex mixture of biotic and abiotic factors, such as poor mixing or bioturbation, sediment composition (grain size and distribution, sediment water content), energy stress conditions (low food, electron acceptors, availability of dissolved substrates and metabolites), and/or predatory pressures and competition.

Most of the cells in the water were free. Attached bacteria are less abundant in many pelagic marine ecosystems than are free-living bacteria. They generally account for less than $5 \%$ of the total bacteria, but this can rise to $10 \%$ (Lapoussière et al., 2011). However, particleattached bacteria can form a much greater fraction (up to $96 \%$ ) of the total bacteria in estuarine systems (Lapoussière et al., 2011). We found that they accounted for less than 20\% of the total suspended cells until the shear velocities increased above $5 \mathrm{~cm} . \mathrm{s}^{-1}$, except in the samples taken on July 21 (Fig 5A). Previous studies have demonstrated that the abundance (or biomass) of particle-attached bacteria depended on the number and/or size of particles available for attachment (Cho and Azam, 1988; Garneau et al., 2009; Lapoussière et al., 
2011). We see a negative relationship between the attached bacteria and the POM in the samples taken on July $21(\mathrm{r}=-0.97, \mathrm{p}<0.05)$ and July $22(\mathrm{r}=-0.88, \mathrm{p}<0.05)$. The high density of motile grazers caused the surface of the bed to be strongly pelletised, which significantly increased the velocity at which eroded sediment settled. These results may also be influenced by the fact that the abundance (or biomass) of particle-attached bacteria is linked to the biogeochemical composition of the suspended material (Fandino et al., 2001; Wang and Yin, 2009). Particle-attached bacteria can play an important role in the transformation of freshly produced POC despite their small contribution (often less than 30\%) to total bacterial biomass (Ghiglione et al., 2009). The positive correlation between leucine aminopeptidase activity and attached cells $(r=0.45, p<0.05)$ supports this idea. Extracellular enzymes may be important for the dispersion or release of attached microbial cells.

Few of the resuspended cells were alive, in contrast to the percent of living cells in the sediment (around 50\%). Thus dead cells (those with damaged membranes) accounted for the greatest fraction $(70-74 \%)$ of resuspended bacterial assemblages in all samples analyzed. These results suggest that the high mechanical stress produced by the shear velocity interferes with the benthic cells, as there were many active cells in the sediment. But whether the cells were attached or free did not seem to be important, as we found significant positive relationships between the attached and active cells $(\mathrm{r}=0.98, \mathrm{p}<0.05)$ and between free and active cells $(r=0.90, p<0.05)$. Nevertheless, our results corroborate Pusceddu et al. (2005) who concluded that the metabolically active bacteria can respond differently to resuspensions of sediment produced by low and high energies. They showed that disturbing a sediment with low-energy force produced a slightly positive response from the active bacterial fraction only during the initial resuspension event. But we found high shear velocities also enriched the resuspended active cells (Fig.4D), unlike Pusceddu et al (2005), who observed that the metabolically active bacteria decreased when turbulence was high. We conclude that 
disturbing the sediment with high-energy forces has little effect on the fraction of metabolically active bacteria resuspended.

Many studies (Chróst and Riemann, 1994; Cotner, 2000; Ritzrau and Graf, 1992; Ritzrau, 1996) have demonstrated that resuspending sediment enhances the microbial dynamics and enzyme activities in the bottom layers of water. The extent to which sediment resuspension affects the enzyme activity in the water column depends on the characteristics of the suspended matter and on the depth of the water column (Ziervogel and Arnosti, 2009). We found that the POM was positively correlated with both the $\beta$-glucosidase $(r=0.52, p<0.05)$ and leucine aminopeptidase $(\mathrm{r}=0.66, \mathrm{p}<0.05)$ activities, as was the PIM concentration ( $\mathrm{r}=0.50, \mathrm{p}<0.05$ for $\beta$-glucosidase and $\mathrm{r}=0.63, \mathrm{p}<0.05$ for leucine aminopeptidase). Microphytobenthic algae also channel a major fraction of their total primary production into the synthesis of extracellular polymeric substances and are thus a significant source of oxygen and organic matter for the growth of benthic bacteria (Boer et al., 2009; De Brouwer and Stal, 2001; Underwood and Kromkamp, 1999). Both the $\beta$-glucosidase $(r=0.72, p<0.05)$ and leucine aminopeptidase activities $(\mathrm{r}=0.77, \mathrm{p}<0.05)$ were positively correlated with the chlorophyll $a$ concentration. The association of specific enzymes with the EPS matrix may prolong their activities and help them resist fluctuations in the environment. The activities of enzymes and their patterns in the Delaware estuary were probably affected by the sedimentassociated microorganisms resuspended into the bottom water layers, increasing the number of microbial cells and the hydrolytic activities of the extracellular enzymes (Ziervogel and Arnosti, 2009).

\section{Erosion and enrichment of prokaryotic OTUs}

Proteobacteria are the most abundant bacteria in most surface marine sediments. They can account for over $50 \%$ of the microbial biomass (Bowman and McCuaig, 2003; Kim et al., 
2008, Pachiadaki et al., 2011). Gamma-Proteobacteria seems to be the most significant clade in most marine sediments (Inagaki et al., 2003; Feng et al., 2009; Polymenakou et al., 2005). Gamma-Proteobacteria accounted for up to $10 \%$ of the total cells in the upper 2-cm layer of sediment and for $20 \%$ of the prokaryotic rRNA in the Smeerenburgfjorden sediments (Ravenschlag et al., 2001). The percentages are lower than those in our samples: GammaProteobacteria accounted for up to $50 \%$ of our total cells (Fig. 7). Analysis of the structures of resuspended prokaryotic communities indicated a sequential enrichment in bacterial OTUs with increasing shear velocity. Pseudomonadal OTUs predominated under low stress condition. But the richness of erodimeter water was always lower than that of the sediment. These increases were partly due to the emergence of Actinobacteria and Chromatiales OTUs. These Bacteria are often found in sediments like those at Brouage mudflat that are exposed to sunlight due to tides and shallow water (Borin et al., 2009). Here, some Cyanobacteria OTUs appeared in the erodimeter water when shear were low, and reappeared when shear velocities were high. The strong hydrodynamic forces encountered at the field site led to constant vertical and horizontal mixing of the upper five centimeters of sediment (Hedtkamp, 2005). This can impose strong selective pressure on the microbial community and restrict access to this habitat to a relatively narrow range of Bacteria that can cope with occasional resuspension, the physical abrasion generated by moving sediment particles, grazing, and rapid fluctuations in the concentrations of oxygen and other nutrients (Boer et al., 2009).

Some authors have suggested that the bacteria attached to particles are phylogenetically different from free-living bacteria (Crump et al., 1999; Gliglione et al., 2009). The present study results do not support this idea: discrepancies may be due to differences in the techniques used, or in the types of particles and trophic conditions. Attached bacteria may be ubiquitous species and probably result from rapid exchanges with the more diverse reservoir of free-living communities. The large number of similar OTUs we found in attached and free- 
living bacteria leads us to believe that free-living and attached bacteria are not separate entities but interacting assemblages, as suggested by Riemann and Winding (2001). Bacteria often seem to development concomitantly with benthic microalgae and they adapt quickly to microalgal exudates by changing the profile of their enzymatic activities. The composition of our bacterial communities differed markedly, depending on the presence (July 17) or absence (July 21) of a microphytobenthic biofilm, in agreement with Lubarsky et al. (2010) (see also Dupuy et al. this issue).

The resuspension produced by our technique provided a higher archaeal specific richness (30 OTUs on average) than Bacteria. However, this applied only to attached cells and samples produced using the highest shear rates $\left(>7 \mathrm{~cm} \mathrm{~s}^{-1}\right)$. The presence of large amounts of Euryarchaeota and Crenarchaeota generally agrees with the clone library studies of Kim et al. (2005; 2008). But they found that Euryarchaeota seemed to be more abundant and diverse than we do. Most of the archaeal sequences in all our samples were of unidentified classes, but we did find Thermoprotei, a group that includes anaerobes and sulfur reducers. Methanomicrobia were the most abundant methanogens. Methanomicrobiales may have occurred in the sulfate-free layers because there was less competition from sulfate reducers. They use substrates released by decaying algae and other organisms, like methylamines and dimethylsulfide. These substrates are not used by most other physiological groups and are mostly found near the surface of the sediment (Wilms et al., 2006).

\section{Conclusions}

We have identified two distinct patterns of resuspended prokaryotic cells, produced by applying different shear stresses to the sediment. Friction velocities of less than $5 \mathrm{~cm} \mathrm{~s}^{-1}$, corresponding to a normal low choppy tide, lead to the resuspension of cells that are mostly free-living, regardless of the physico-chemical characteristics of the sediment or the 
development of a biofilm on its surface. These cells are mainly Cyanobacteria and GammaProteobacteria that secreted some extracellular enzymes and can become integrated into, and thus affect, the coastal planktonic microbial food web (Garstecki et al., 2002). Friction velocities greater than $5 \mathrm{~cm} \mathrm{~s}^{-1}$, corresponding to rough tides with waves, favour the resuspension of attached cells. Studies on the effects of fluid shear on microbial activity in the water column have shown that particle-attached bacteria benefit nutritionally more than freeliving forms given that the host particle is large enough (Jumars et al., 1993; Lazier and Mann, 1989). It is under these circumstances that the greatest proportion of bacterial and archaeal OTUs with different functions are recruited from deep sediment. The shear velocity was strongly correlated with hydrolytic enzyme activities and linked to the increase in resuspended intact cells (potentially active). These attached prokaryotes could provide organic matter to the pelagic zone and enhance the breakdown of benthic organic matter (Ståhlberg et al., 2006). Resuspended sediments that are rich in organic and inorganic nutrients may stimulate the large scale production of planktonic heterotrophs, even at low temperatures (Fiordelmondo 2004).

\section{Acknowledgements}

This study was supported by the French ANR (National Research Agency) through the VASIREMI project "Trophic significance of microbial biofilms in tidal flats" (contract ANR420 06-BLAN-0393-01). The English text was edited by Dr Owen Parkes.

\section{References}

Alkemade, R., Wielemaker, A., de Jong, S.A., Sandee, A.J.J. 1992. Experimental evidence for the role of bioturbation by the marine nematode Diplolaimella bruciei in stimulating the mineralization of Spartina anglica detritus. Marine Ecology Progress Series, 90, 149-155. 
Altschul, S.F., Madden, T.L., Schaffer, A.A., Zhang, J., Zhang, Z., Miller, W., Lipman, D.J. 1997. Gapped BLAST and PSI-BLAST: a new generation of protein database search programs. Nucleic Acids Research, 25, 3389-3402

Aminot, A., Chaussepied, M., 1983. Manuel des analyses chimiques en milieu marin. CNEXO, Brest.

Batisson, I., Crouzet, O., Besse-Hoggan, P., Sancelme, M., Mangot, J. F., Mallet, C., Bohatier, J. (2009). Isolation and characterization of mesotrione-degrading Bacillus sp. from soil. Environmental Pollution, 157, 1195-1201.

Blanchard, G.F., Simon Bouhet B., Guarini, J.-M. (2002). Properties of the dynamics of intertidal microphytobentic biomass. Journal of the Marine Biological Association of the UK, 82, 1027-1028

Blanchard, G.F., Guarini, J.-M., Bacher, C., Huet, V. 1998. Contrôle de la dynamique à court terme du microphytobenthos intertidal par le cycle exondation-submersion. Comptes Rendus de l'Académie des Sciences, 321,501-508

Blanchard, G.F., Sauriau, P-G., Cariou-Le Gall, V., Garet, M.J., Olivier, F. 1997. Kinetics of tidal resuspension of microbiota: testing the effects of sediment cohesiveness and bioturbation using flume experiments. Marine Ecology Progress Series, 151, 17-25.

Böer, S.I., Hedtkamp, S.I., van Beusekom, J.E., Fuhrman, J. A., Boetius, A., Ramette, A. 2009. Time-and sediment depth-related variations in bacterial diversity and community structure in subtidal sands. The ISME journal, 3, 780-791.

Borin, S., Brusetti, L., Daffonchio, D., Delaney, E., Baldi, F. 2009. Biodiversity of prokaryotic communities in sediments of different sub-basins of the Venice lagoon. Research in Microbiology, 160, 307-314. 
Bowman, J.P., McCuaig, R.D. 2003. Biodiversity, community structural shifts, and biogeography of prokaryotes within Antarctic continental shelf sediment. Applied and Environmental Microbiology, 69, 2463-2483.

Brouwer, J.F.C., de Stal, L.J 2002. Daily fluctuations of exopolymers in cultures of the benthic diatoms Cylindrotheca closterium and Nitzchia sp. (Bacillariophyceae). Journal of Phycology, 38, 464-472.

Brussaard, C.P. 2004. Optimization of procedures for counting viruses by flow cytometry. Applied and Environmental Microbiology, 70, 1506-1513.

Cho, B.C., Azam, F. 1988. Major role of bacteria in biogeochemical fluxes in the ocean's interior. Nature, 332, 441-443.

Chróst, R.J., Riemann, B. 1994. Storm-stimulated enzymatic decomposition of organic matter in benthic/pelagic coastal mesocosms. Marine Ecology Progress Series, 108, 185-192.

Clarke K.R., Warwick R.W. 2001. Change in Marine Communities: An Approach to Statistical Analysis and Interpretation, 2nd edn. Primer-E, Plymouth.

Cotner, J.B., Johengen, T.H. Biddanda, B.A. 2000. Intense winter heterotrophic production stimulated by benthic resuspension. Limnology and Oceanography, 45, 1672-1676.

Crump, B.C, Armbrust, E.V., Baross, J.A. 1999. Phylogenetic analysis of particle-attached and free-living bacterial communities in the Columbia River, its estuary, and the adjacent coastal ocean. Applied and Environmental Microbiology, 65, 3192-3204.

Danovaro, R., Dell'Anno, A., Trucco, A., Serresi, M., Vanucci, S. 2001. Determination of virus abundance in marine sediments. Applied and Environmental Microbiology, 67, 13841387. 
De Brouwer, J.F.C., Stal, L.J. 2001. Short-term dynamics in microphytobenthos distribution and associated extracellular carbohydrates in surface sediments of an intertidal mudflat. Marine Ecology Progress Series, 218, 33-44.

Dubois, M., Gilles, K.A, Hamilton, J.K., Rebers, P.A., Smith, F., 1956. Colorimetric method for determination of sugars and related substances. Analytical Chemistry, 28, 350-356.

Duhamel, S., Jacquet, S. 2006. Flow cytometric analysis of bacteria-and virus-like particles in lake sediments. Journal of Microbiological Methods, 64, 316-332.

Fandino, L.B., Riemann, L., Steward, G.F., Long, R.A., Azam, F. 2001. Variations in bacterial community structure during a dinoflagellate bloom analyzed by DGGE and 16S rDNA sequencing. Aquatic Microbial Ecology, 23, 119.

Feng, B.W., Li, X.R., Wang, J.H., Hu, Z.Y., Meng, H., Xiang, L.Y., Quan, Z.X. 2009. Bacterial diversity of water and sediment in the Changjiang estuary and coastal area of the East China Sea. FEMS Microbiology Ecology, 70, 236-248.

Fiordelmondo, C., Pusceddu, A. 2004. Short-term response of benthic bacteria and nanoflagellates to sediment resuspension: an experimental study. Chemistry and Ecology, $20,107-121$

Garneau, M.È., Vincent, W.F., Terrado, R., Lovejoy, C. 2009. Importance of particleassociated bacterial heterotrophy in a coastal Arctic ecosystem. Journal of Marine Systems, $75,185-197$.

Garstecki, T., Wickham, S. A., Arndt, H. 2002. Effects of experimental sediment resuspension on a coastal planktonic microbial food web. Estuarine, Coastal and Shelf Science, 55, 751762. 
Gerbersdorf, S.U., Bittner, R., Lubarsky, H., Manz, W., Paterson, D.M. 2009. Microbial assemblages as ecosystem engineers of sediment stability. Journal of Soils and Sediments, 9, 640-652.

Ghiglione, J.F., Conan, P., Pujo-Pay, M. 2009. Diversity of total and active free-living vs. particle-attached bacteria in the euphotic zone of the NW Mediterranean Sea. FEMS Microbiology Letters, 299, 9-21.

Goto, N., Mitamura O., Terai, H. 2001. Biodegradation of photosynthetically produced extracellular organic carbon from intertidal benthic algae. Journal of Experimental Marine Biology and Ecology, 257, 73-86.

Grabowski, R.C., Droppo, I.G., Wharton, G. 2011. Erodibility of cohesive sediment: the importance of sediment properties. Earth-Science Reviews, 105, 101-120.

Guizien, K., Orvain F., Duchene J.C., Le Hir P. 2012. Accounting for rough bed friction factors of mud beds due to biological activity in erosion experiments. Journal of Hydraulic Engineering, 138, 979-984.

Guizien, K., Dupuy, C., Ory, P., Montanié, H., Hartmann, H., Chatelain, M., Karpytchev, M. 2014. Microorganism dynamics during a rising tide: Disentangling effects of resuspension and mixing with offshore waters above an intertidal mudflat. Journal of Marine Systems, $129,178-188$.

Hamels, I., Muylaert, K., Casteleyn, G., Vyverman, W. 2001. Uncoupling of bacterial production and flagellate grazing in aquatic sediments: a case study from an intertidal flat. Marine Ecology Progress Series, 25, 31-42.

Hammer, Ø., Harper, D.A.T., Ryan, P.D. 2001. PAST: Paleontological Statistics Software Package for Education and Data Analysis. Palaeontologia Electronica 4, 1-9. 
Hedtkamp, S. 2005. Shallow subtidal sand: Permeability, nutrient dynamics microphytobenthos and organic matter. Christian-Albrechts-Universität, Kiel.

Héral, M., Bacher, C., Deslous-Paoli, J.M. 1989. La Capacité trophique des bassins ostréicoles. In: Troadec JP (ed) L'homme et les ressources halieutiques : essai sur l'usage d'une ressource renouvelable Ifremer, Brest, pp 225-259.

Inagaki, F., Suzuki, M., Takai, K., Oida, H., Sakamoto, T., Aoki, K., .. \& Horikoshi, K. 2003. Microbial communities associated with geological horizons in coastal subseafloor sediments from the Sea of Okhotsk. Applied and Environmental Microbiology, 69, 72247235.

Jumars, P.A., Deming, J.W., Hill, P.S., Karp-Boss, L., Yager, P.L., Dade, W.B. 1993. Constraints on marine osmotrophy in an optimal foraging context. Marine Microbial Food Webs, 7, 121-159

Kim, B.S., Kim, B.K., Lee, J.H., Kim, M., Lim, Y.W., Chun, J. 2008. Rapid phylogenetic dissection of prokaryotic community structure in tidal flat using pyrosequencing. Journal of Microbiology, 46, 357-363.

Kim, B.S., H.M. Oh, H. Kang, J. Chun. 2005. Archaeal diversity in tidal flat sediment as revealed by $16 \mathrm{~S}$ rDNA analysis. Journal of Microbiology, 43, 144-151.

Kopczynski, E.D., Bateson, M.M., Ward, D.M. 1994. Recognition of chimeric small-subunit ribosomal DNAs composed of genes from uncultivated microorganisms. Applied and Environmental Microbiology, 60, 746-748

Lapoussière, A., Michel, C., Starr, M., Gosselin, M., Poulin, M. 2011. Role of free-living and particle-attached bacteria in the recycling and export of organic material in the Hudson Bay system. Journal of Marine Systems, 88, 434-445. 
Lazier, J.R.N., Mann, K.H. 1989. Turbulence and the diffusive layers around small organisms. Deep Sea Research Part A. Oceanographic Research Papers, 36, 1721-1733.

Le Hir, P., Cann, P., Jestin, H., Bassoulet, P., 2006. Instrumentation légère pour la mesure de leérodabilité des sédiments vaseux ou sablovaseux.” Proc. IXémes Journées Nationales Génie Côtier-Génie Civil, PARALIA, Nantes, France.

Leguerrier, D., Niquil, N., Boileau, N., Rzeznik, J., Sauriau, P.G., Le Moine, O., Bacher, C. 2003. Numerical analysis of the food web of an intertidal mudflat ecosystem on the Atlantic coast of France. Marine Ecology Progress Series, 246, 17-37.

Lorenzen, C.J., 1966. A method for the continuous measurement of in vivo chlorophyll concentration. Deep-Sea Research, 13, 223-227.

Lubarsky, H.V., Hubas, C., Chocholek, M., Larson, F., Manz, W., Paterson, D.M., Gerbersdorf, S.U. 2010. The stabilisation potential of individual and mixed assemblages of natural bacteria and microalgae. PloS one, 5, e13794.

Maidak, B.L., Cole, J.R., Parker, Jr. C.T., Garrity, G.M., Larsen, N., Li B., Lilburn, T.G., McCaughey, M.J., Olsen, G.J., Overbeek, R., Pramanik, S., Schmidt, T.M., Tiedje, J.M., Woese, C.R. 1999. A new version of the RDP (ribosomal database project). Nucleic Acids Research, 27, 171-173

Mallet, C., Debroas, D. 1999. Relations between organic matter and bacterial proteolytic activity in sediment surface layers of a eutrophic lake (Lake Aydat, Puy de Dôme, France). Archiv für Hydrobiologie, 145, 39-56.

Mallet, C., Debroas, D. 2001. Regulation of $\beta$-and $\alpha$-glycolytic activities in the sediments of a eutrophic lake. Microbial Ecology, 41, 106-113. 
Manini, E., Danovaro, R. 2006. Synoptic determination of living/dead and active/dormant bacterial fractions in marine sediments. FEMS Microbiology Ecology, 55, 416-423.

Mariotti, G., Fagherazzi, S. 2012. Modeling the effect of tides and waves on benthic biofilms. Journal of geophysical research, 117, G04010, doi:10.1029/2012JG002064

McLusky, D.S. 1989. The estuarine ecosystem, Chapman \& Hall, New York, 215 pp.

Middelburg, J.J., Baranguet, C., Boschker, H.T.S., Herman, P.M.J., Moens, T., Heip, C.H.R. 2000. The fate of intertidal microphytobenthos carbon: an in situ 13C-labeling study. Limnology and Oceanography, 45, 1224-1234.

Moeseneder, M.M., Herndl, G.J. 1995. Influence of turbulence on bacterial production in the sea. Limnology and Oceanography, 40, 1466-1473.

Orvain, F., Galois, R., Barnard, C., Sylvestre, A., Blanchard, G., Sauriau, P.-G. 2003. Carbohydrate production in relation to microphytobenthic biofilm development: an integrated approach in a tidal mesocosm. Microbial Ecology, 45, 231-257.

Orvain F., Sauriau P.G., Bacher C., Prineau M. 2006. The influence of sediment cohesiveness on bioturbation effects due to Hydrobia ulvae on the initial erosion of intertidal sediments: A study combining flume and model approaches. Journal of Sea Research, 55, 54-73.

Orvain, F., Sauriau, P.G., Le Hir, P., Guillou, G., Cann, P., Paillard, M. 2007. Spatio-temporal variations in intertidal mudflat erodability: Marennes-Oléron Bay, western France. Continental Shelf Research, 27, 1153-1173.

Pachiadaki, M.G., Kallionaki, A., Dählmann, A., De Lange, G.J., Kormas, K.A. 2011. Diversity and spatial distribution of prokaryotic communities along a sediment vertical profile of a deep-sea mud volcano. Microbial Ecology, 62, 655-668. 
Parkes, R.J., Cragg, B.A., Wellsbury, P. 2000. Recent studies on bacterial populations and processes in subseafloor sediments: a review. Hydrogeology Journal, 8, 11-28.

Pascal, P-Y, Dupuy, C., Richard, P., Mallet, C., Armynot du Châtelet, E., Niquil, N. 2009. Seasonal variation in consumption of benthic bacteria by meio- and macrofauna in an intertidal mudflat. Limnology and Oceanography, 54, 1048-1059.

Paterson, D.M., Black, K.S. 1999. Water flow, sediment dynamics and benthic biology. . In: Nedwell D.B., Raffaelli D.G. (eds), Estuaries. Advances in Ecological Research, 29, 155193.

Polymenakou, P.N., Bertilsson, S., Tselepides, A., Stephanou, E.G. 2005. Bacterial community composition in different sediments from the Eastern Mediterranean Sea: a comparison of four $16 \mathrm{~S}$ ribosomal DNA clone libraries. Microbial Ecology, 50, 447-462.

Porter, E.T., Mason R.P., Sanford L.P. 2010. Effect of tidal resuspension on benthic-pelagic coupling in an experimental ecosystem study. Marine Ecology Progress Series, 413, 33-53.

Pusceddu, A., Fiordelmondo, C., Danovaro, R. 2005. Sediment resuspension effects on the benthic microbial loop in experimental microcosms. Microbial Ecology, 50, 602-613.

Ravenschlag, K., Sahm, K., Amann, R. 2001. Quantitative molecular analysis of the microbial community in marine Arctic sediments (Svalbard). Applied and Environmental Microbiology, 67, 387-395.

Riemann, F., Helmke, E. 2002. Symbiotic relations of sediment-agglutinating nematodes and bacteria in detrital habitats: the enzyme-sharing concept. Marine Ecology, 23, 93-113. 
Riemann, L., Winding, A. 2001. Community dynamics of free-living and particle-associated bacterial assemblages during a freshwater phytoplankton bloom. Microbial Ecology, 42, 274-285.

Ritzrau, W., Graf, G. 1992. Increase of microbial biomass in the benthic turbidity zone of Kiel Bight after resuspension by a storm event. Limnology and Oceanography, 37, 1081-1086.

Ritzrau, W. 1996. Microbial activity in the benthic boundary layer: Small-scale distribution and its relationship to the hydrodynamic regime. Journal of Sea Research, 36, 171-180.

Shapiro, S.S., Wilk, M.B. 1965. An analysis of variance test for normality (complete samples). Biometrika, 52, 591-611.

Schmidt, J.L., Deming, J.W., Jumars, P.A., Keil, R.G. 1998. Constancy of bacterial abundance in surficial marine sediments. Limnology and Oceanography, 43, 976-982

Shimeta, J., Amos, C.L., Beaulieu, S.E., Katz, S.L. 2003. Resuspension of benthic protists at subtidal coastal sites with differing sediment composition. Marine Ecology Progress Series, 259, 103-115.

Ståhlberg, C., Bastviken, D., Svensson, B.H., Rahm, L. 2006. Mineralisation of organic matter in coastal sediments at different frequency and duration of resuspension. Estuarine, Coastal and Shelf Science, 70, 317-325.

Takahashi, E., Ledauphin, J., Goux, D., Orvain, F. 2009. Optimising extraction of extracellular polymeric substances (EPS) from benthic diatoms: comparison of the efficiency of six EPS extraction methods. Marine and Freshwater Research, 60, 1201-1210.

Teal, J.M., 1962. Energy flow in the salt-marsh ecosystem of Georgia. Ecology, 43, 614-624. 
Thingstad, F. 2000. Control of bacterial growth in idealized food webs. In: Kirchman DL (ed) Microbial ecology of the Oceans. Wiley-Liss, New York, pp 229-260.

Underwood, G.J.C., Paterson, D.M. 2003. The importance of extracellular carbohydrate production by marine epipelic diatoms. Advances in Botanical Research, 40, 183-240.

Underwood, G.J.C., Kromkamp, J. 1999. Primary production by phytoplankton and microphytobenthos in estuaries. Advances in Ecological Research, 29, 93-153.

van Duyl, F.C., de Winder, B., Kop, A.J., Wollenzien, U. 1999. Tidal coupling between carbohydrate concentrations and bacterial activities in diatom-inhabited intertidal mudflats. Marine Ecology Progress Series, 191, 19-32.

Wainright, S.C. 1987. Stimulation of heterotrophic microplankton production by resuspended marine sediment. Science, 238, 1710-1712.

Wainright, S.C. 1990. Sediment-to-water fluxes of particulate material and microbes by resuspension and their contribution to the planktonic food web. Marine Ecology Progress Series, 62, 271-281.

Ward, J.H. 1963. Hierarchical grouping to optimize an objective function. Journal of the American Statistical Association, 58, 236-244.

Weerman, E.J., Herman, P.M.J., Van de Koppel, J. 2011. Top-down contral inhibits spatial self-organization of a patterned landscape. Ecology, 92, 487-495.

Wilms, R., Sass, H., Köpke, B., Köster, J., Cypionka, H., Engelen, B. 2006. Specific bacterial, archaeal, and eukaryotic communities in tidal-flat sediments along a vertical profile of several meters. Applied and Environmental Microbiology, 72, 2756-2764. 
Ziervogel, K., Arnosti, C. 2009. Enzyme activities in the Delaware Estuary affected by elevated suspended sediment load. Estuarine, Coastal and Shelf Science, 84, 253-258.

Ziervogel, K., Forster, S. 2006. Do benthic diatoms influence erosion thresholds of coastal subtidal sediments? Journal of Sea Research, 55, 43-53.

\section{Figures captions}

Figure 1: Sampling site.

Figure 2: PCA of sediment environmental and biological parameters (showing the variables: samples 1-3 were taken on July 17, 4-6 on July 21, 7-9 on July 22 and 10-12 on July 24). (prot: protein; colloidal: colloidal carbohydrates from EPS; bound: bound carbohydrates from EPS; chloro: chlorophyll $a$; muf: $\beta$-glucosidase activity; leu: leucine-aminopeptidase activity; OM: organic matter; cells: prokaryotic abundance).

Figure 3: (A) Bacteria and (B) Archaea phyla found in the sediment samples (relative abundance (\%), see Materials and Methods for details) (numbers on the graph represent the richness of taxons). (ungproteobacteria: unidentified Gamma-Proteobacteria; uneuryarchaeota: unidentified Euryarchaeota; uncrenarchaeota: unidentified Crenarchaeota; unarchaea: unidentified Archaea).

Figure 4: (A) Total and free cells enrichments in the erodimeter water obtained by treating samples collected on July 17, 21, 22 and 24, (B) attached cells enrichment and (C) active cells enrichment, at each threshold friction velocity $\left(\mathrm{u}^{*} \mathrm{~cm} \mathrm{~s}^{-1}\right)$.

Figure 5: (A) $\beta$-glucosidase and (B) leucine aminopetidase specific activities in the erodimeter water obtained with each threshold friction velocity $\left(\mathrm{u}^{*} \mathrm{~cm} \mathrm{~s}^{-1}\right)$ from samples obtained on July 17, 21, 22 and 24.

Figure 6: PCA of erodimeter water environmental and biological parameters (showing the variables; samples 1-6 from July 17, 7-10 from July 21, 11-15 from July 22 and 16-21 from July 24). (attached: enrichment of attached prokaryotic cells; live: enrichment of live prokaryotic cells; tot: enrichment of prokaryotic cells; free: enrichment of free prokaryotic cells; muf: $\beta$-glucosidase activity; leu: leucine-aminopeptidase activity; MOP: particular organic matter; MP: particulate matter; $\mathrm{X}$ : threshold friction velocity $\left(\mathrm{u}^{*}\right)$; chloro: chlorophyll a).

Figure 7: Bacterial phyla in the erodimeter water (relative abundance (\%), see Materials and Methods for details) after treating the July 17 sediment at each threshold friction velocity $\left(\mathrm{u}^{*} \mathrm{~cm} \mathrm{~s}^{-1}\right)$ : attached (A) and free cells (B) DNA ; (C) free cell DNA in the July 21erodimeter water; (D) attached cell DNA in the July 22 erodimeter water; (E) attached and (F) free cell 
789 DNA in the July 24 erodimeter water (numbers on the graph represent the richness of taxons).

790 (ungproteobacteria: unidentified Gamma-Proteobacteria).

791 Figure 8: Archaeal phyla recovered (relative abundance (\%), see Materials and Methods for 792 details) from the sediment sample at each threshold friction velocity $\left(\mathrm{u}^{*} \mathrm{~cm} \mathrm{~s}^{-1}\right)$. Attached cell 793 DNA in the erodimeter water for (A) July 17 of the, (B) July 21, (C) July 22 and (D) July 24. 794 (numbers on the graph represent the richness of taxons). (uneuryarchaeota: unidentified 795 Euryarchaeota; uncrenarchaeota: unidentified Crenarchaeota; unarchaea: unidentified 796 Archaea). 
$798 \quad$ Fig1

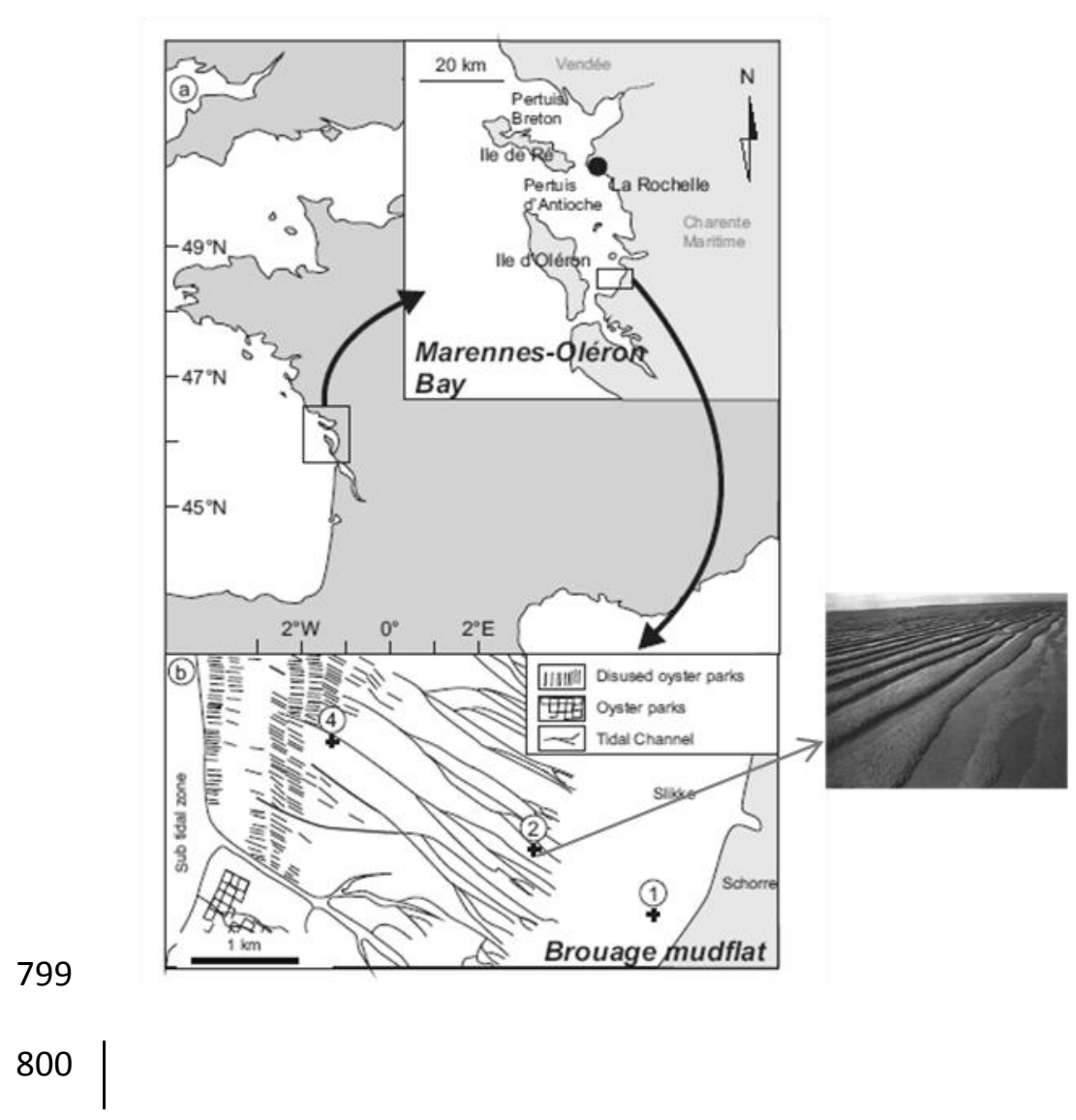



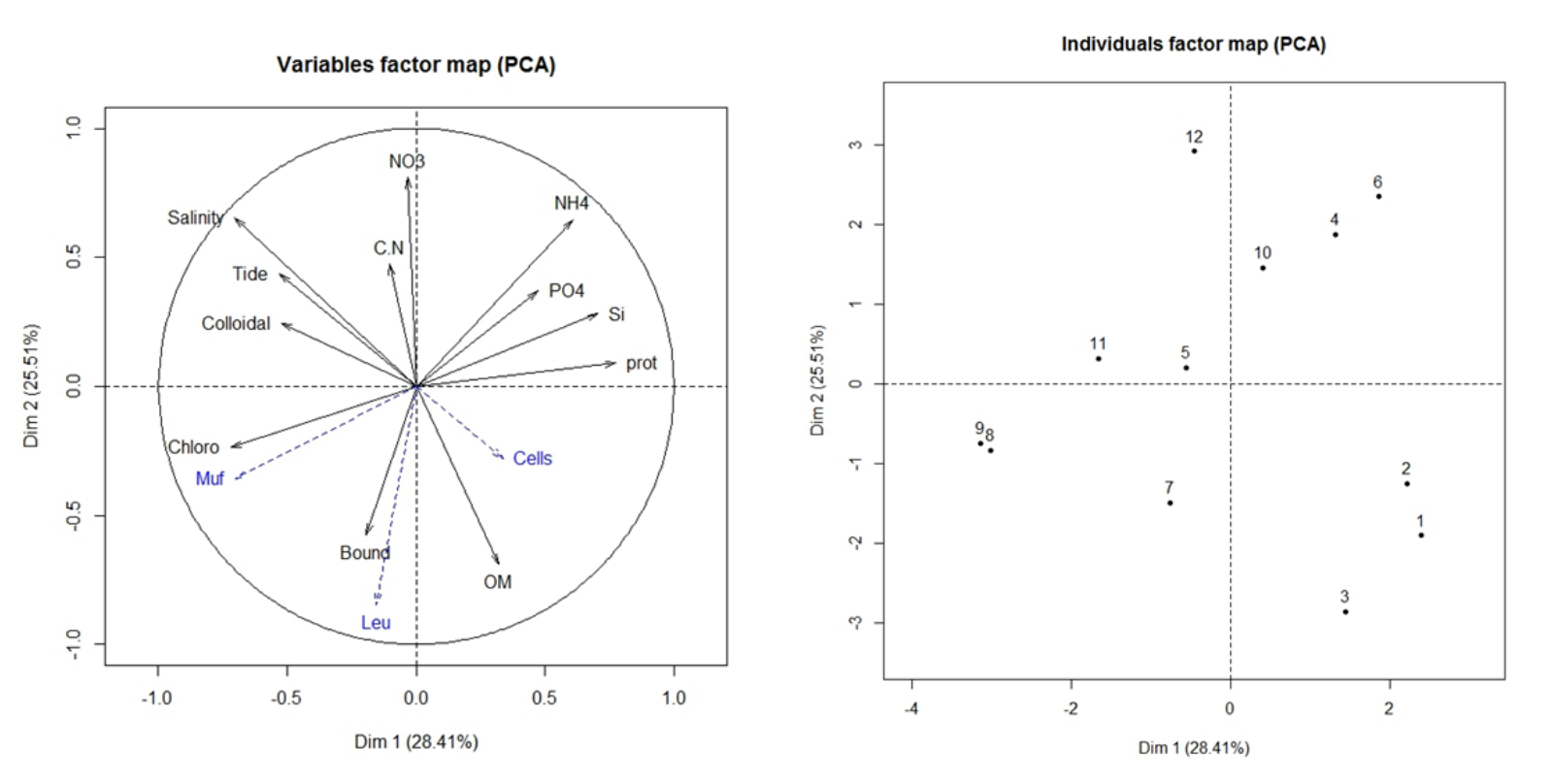

804 

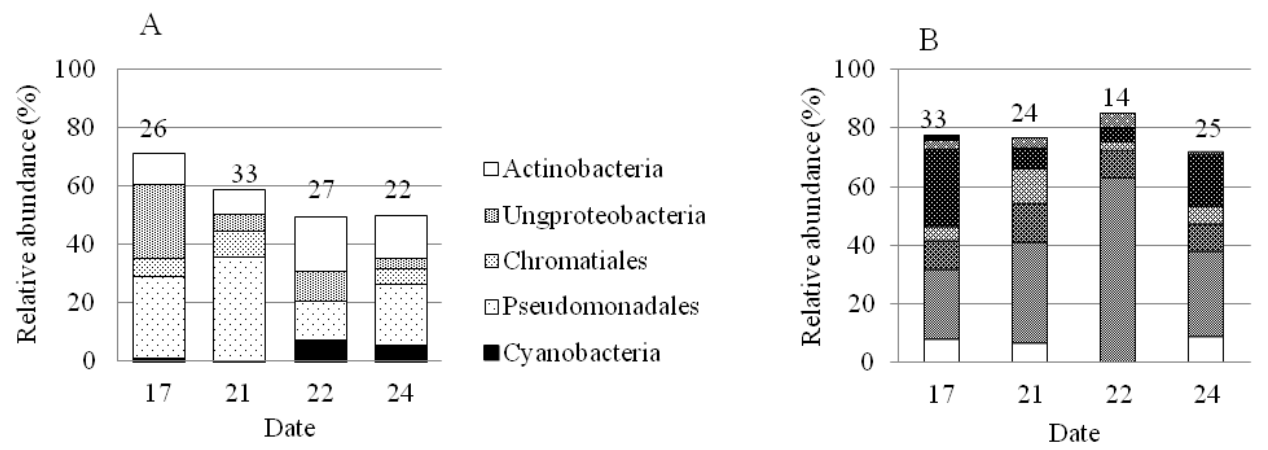

- Thermoplamata

Methanomicrobia

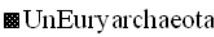

㘣Thermoprotei

图MGI

口UnCrenarchaeota

$\square$ UnArchaea

806 
$809 \quad$ Fig4
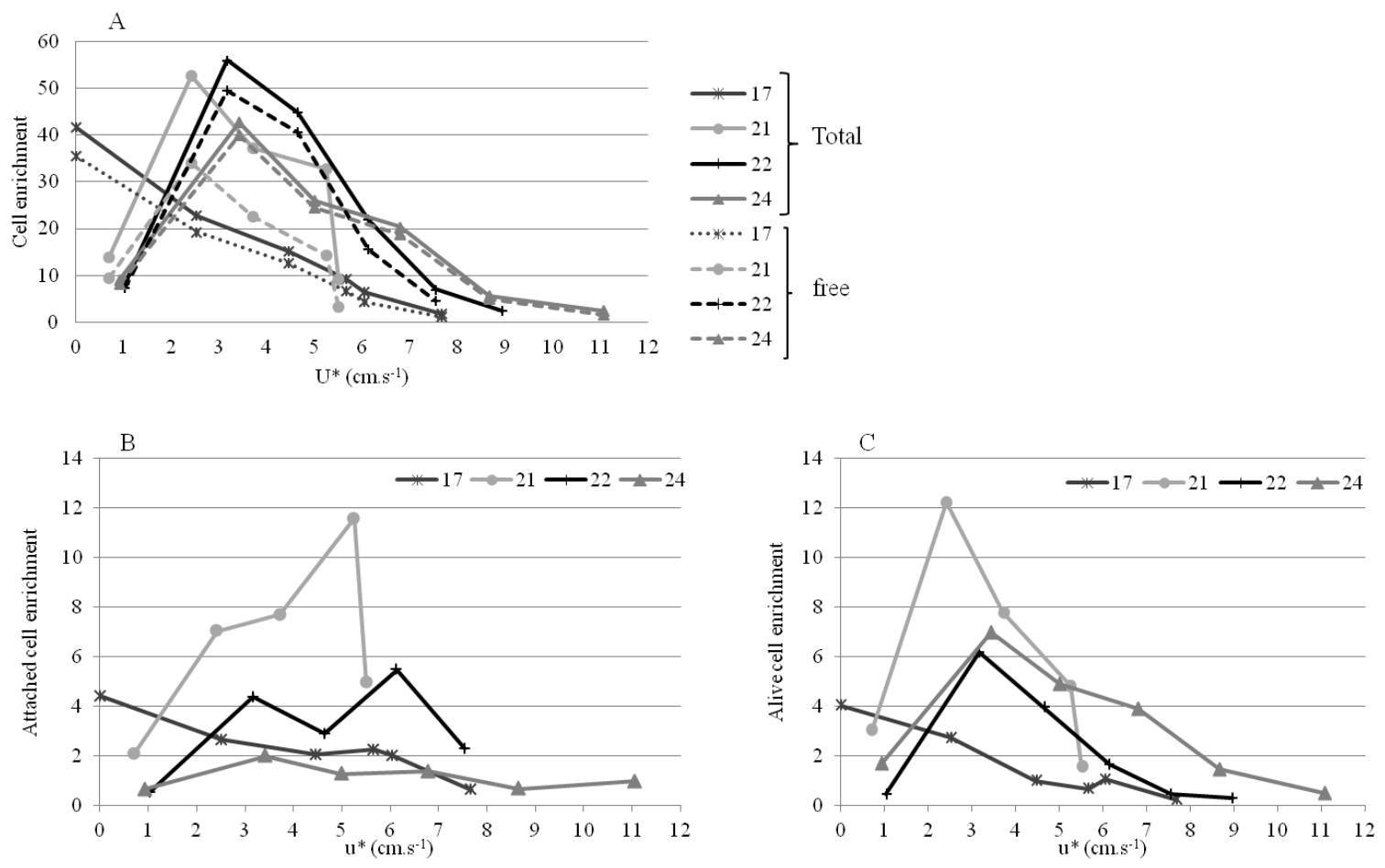

811 

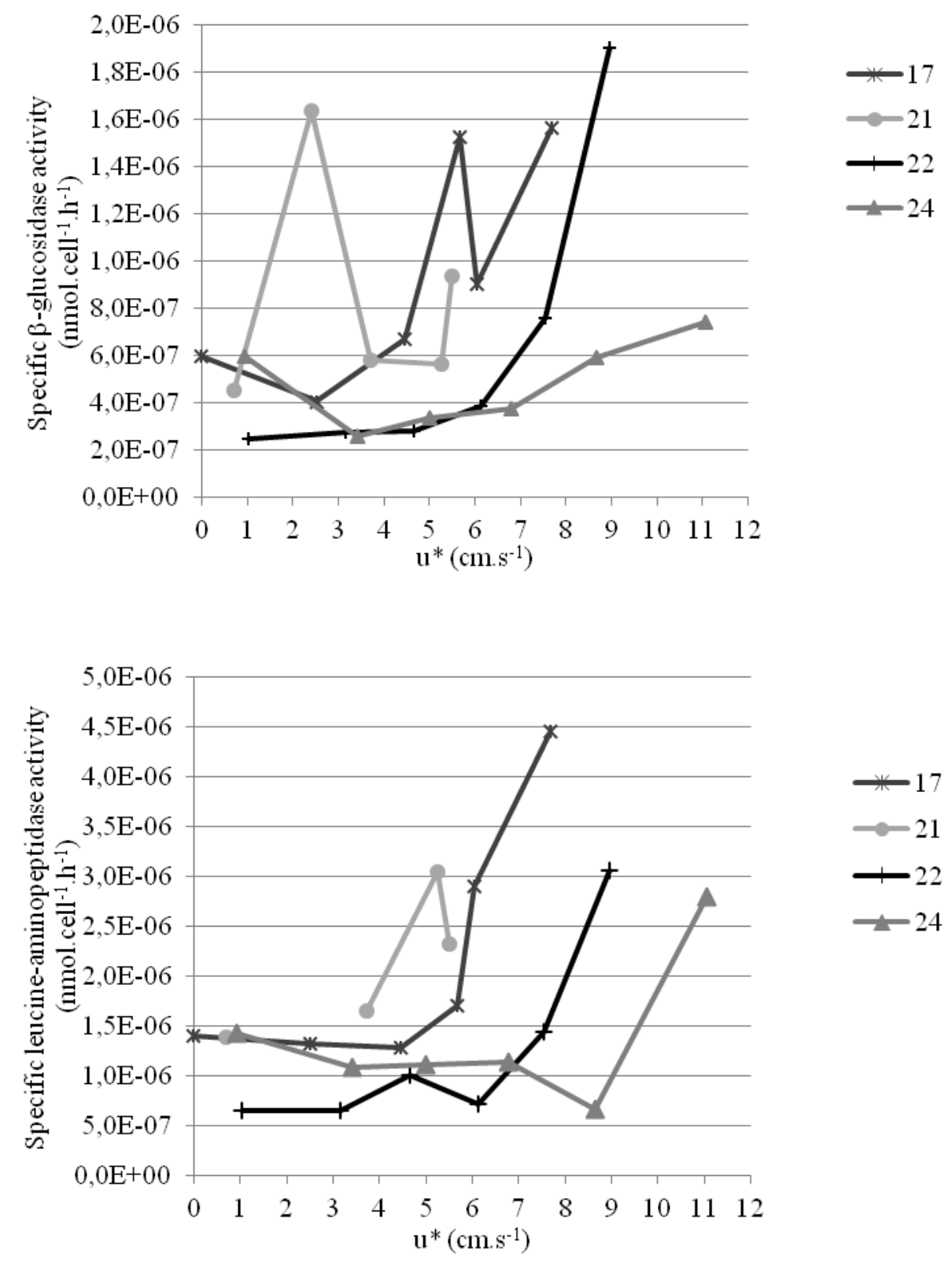
$817 \quad$ Fig6
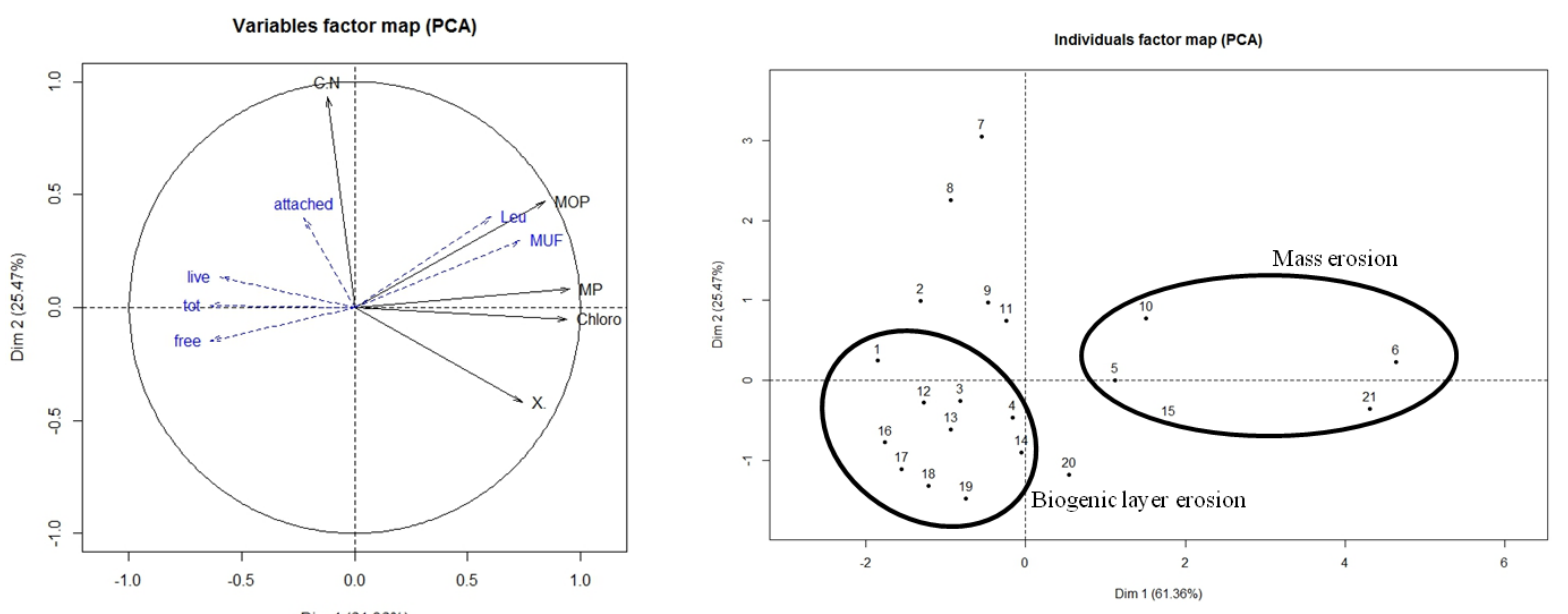

818

819 

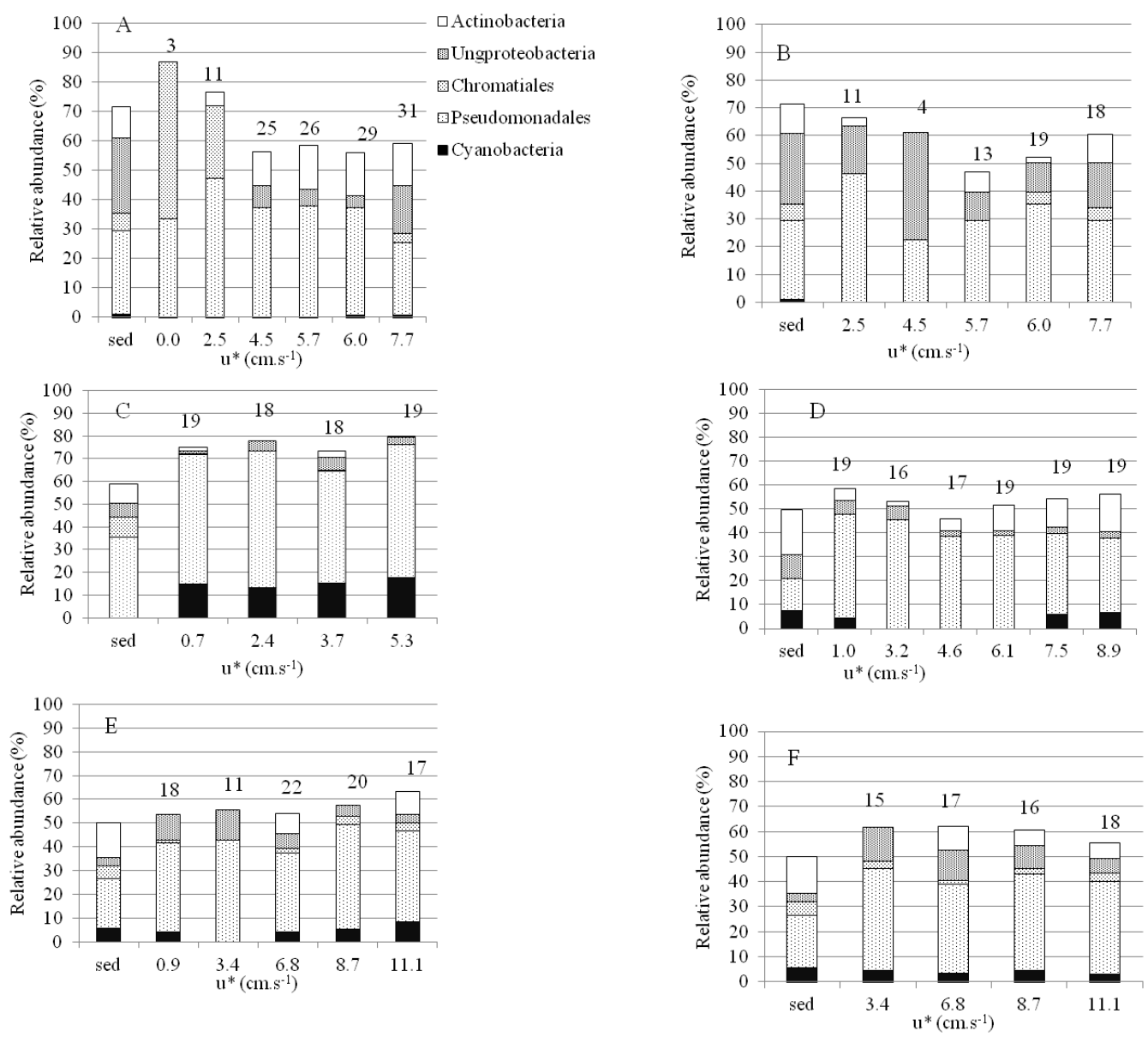

822 

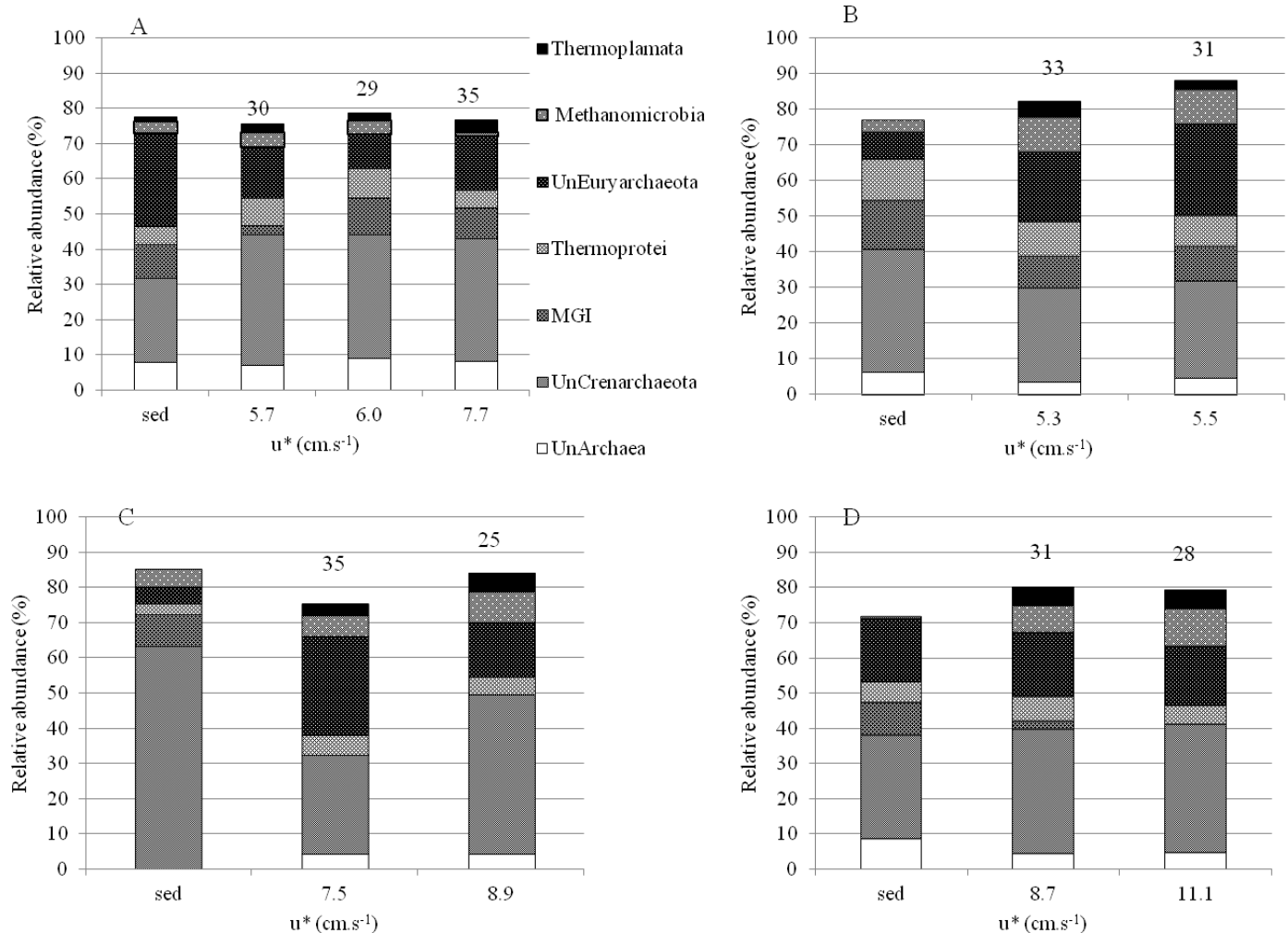
826 Table 1 : Environmental and biological parameters of the sediment cores (means and standard deviation in brackets). (Leu: potential leucine aminopeptidase 827 activity. Muf: potential $\beta$-glucosidase activity). Different letters in the same column indicate differences between sampling date (according to an analysis of 828 variance followed by Tükey post hoc test, $p<0.05$; ns: no significant difference)

829

\begin{tabular}{|c|c|c|c|c|c|c|c|c|c|c|c|c|c|c|c|}
\hline $\begin{array}{l}\text { Sampling } \\
\text { dates }\end{array}$ & $\begin{array}{l}\text { Tide } \\
\text { coefficient }\end{array}$ & $\begin{array}{l}\text { Salinity } \\
(\mathrm{o} / \mathrm{oo})\end{array}$ & $\begin{array}{l}\text { NH4 } \\
\mu \mathrm{mol} . \mathrm{L}^{-1}\end{array}$ & $\begin{array}{l}\text { NO3 } \\
\mu \mathrm{mol} . \mathrm{L}^{-1}\end{array}$ & $\begin{array}{l}\text { PO4 } \\
\mu \mathrm{mol} . \mathrm{L}^{-1}\end{array}$ & $\begin{array}{l}\text { Si } \\
\mu \mathrm{mol} . \mathrm{L}^{-1}\end{array}$ & $\begin{array}{l}\text { Organic } \\
\text { matter } \\
\text { g. } \mathrm{g}^{-1}\end{array}$ & $\begin{array}{l}\text { Colloidal } \\
\text { carbohydr } \\
\text { ates } \\
\mu \mathrm{g} \cdot \mathrm{g}^{-1}\end{array}$ & $\begin{array}{l}\text { Bound } \\
\text { carbohydr } \\
\text { ates } \\
\mu \mathrm{g} \cdot \mathrm{g}^{-1}\end{array}$ & $\begin{array}{l}\text { Proteins } \\
\mu \mathrm{g} \cdot \mathrm{g}^{-1}\end{array}$ & $\mathrm{C} / \mathrm{N}$ & $\begin{array}{c}\text { Chloro } a \\
\mu \mathrm{g} \cdot \mathrm{g}^{-1}\end{array}$ & $\begin{array}{l}\begin{array}{l}\text { Prokary } \\
\text { otes }\end{array} \\
10^{8} \text { cell.g } \\
1\end{array}$ & $\begin{array}{l}\text { Leu } \\
\mathrm{nmol} / \mathrm{g} / \mathrm{h}\end{array}$ & $\begin{array}{l}\text { Muf } \\
\mathrm{nmol} / \mathrm{g} / \mathrm{h}\end{array}$ \\
\hline 17 & 63 & $41.7(1.3) \mathrm{a}$ & $21.2(4.1) \mathrm{ab}$ & $1.2(0.4) \mathrm{a}$ & $1.4(0.3)$ & $94.2(3.8) \mathrm{a}$ & $0.2(0.05) \mathrm{ns}$ & $5.1(2.1) \mathrm{a}$ & $11.9(0.8) \mathrm{ns}$ & $4.3(0.2) \mathrm{ns}$ & $7.3(0.3) \mathrm{ns}$ & $7.6(1.5) \mathrm{ns}$ & $8.5(0.1) \mathrm{a}$ & $127,8(0.1) \mathrm{a}$ & $51,6(0.2) \mathrm{a}$ \\
\hline 21 & 82 & $46.4(0.4) b$ & $34.6(6.7) \mathrm{a}$ & $4.7(2.7) \mathrm{ab}$ & $1.7(0.8)$ & $96.0(0.8) \mathrm{a}$ & $0.1(0.03) \mathrm{ns}$ & $10.8(1.7) b$ & $11.1(1.3) \mathrm{ns}$ & $4.4(0.4) \mathrm{ns}$ & $7.8(0.3) \mathrm{ns}$ & $7.2(0.5) \mathrm{ns}$ & $5.6(0.2) \mathrm{b}$ & $104,6(0.2) b$ & $51,5(0.2) \mathrm{a}$ \\
\hline 22 & 81 & $47.6(1.1) b$ & $14.9(8.9) \mathrm{b}$ & $1.2(0.7) \mathrm{a}$ & $1.2(0.2)$ & $75.8(10.0) \mathrm{b}$ & $0.1(0.07) \mathrm{ns}$ & $11.4(1.6) b$ & $12.5(1.1) \mathrm{ns}$ & $3.8(0.3) \mathrm{ns}$ & $7.3(0.6) \mathrm{ns}$ & $9.2(1.6) \mathrm{ns}$ & $6.3(0.2) \mathrm{c}$ & $131,0(0.2) \mathrm{a}$ & $105,3(0.2) b$ \\
\hline 24 & 72 & $48.1(1.9) \mathrm{b}$ & $26.1(5.5) \mathrm{ab}$ & $10.3(5.2) b$ & $1.2(0.3)$ & $96.1(5.8) \mathrm{a}$ & $0.1(0.01) \mathrm{ns}$ & $8.4(1.1) \mathrm{ab}$ & $10.6(1.1) \mathrm{ns}$ & $3.8(0.3) \mathrm{ns}$ & $9.5(3.2) \mathrm{ns}$ & $8.9(2.0) \mathrm{ns}$ & $8.2(0.1) \mathrm{a}$ & $104,7(0.2) b$ & $49,1(0.3) \mathrm{a}$ \\
\hline
\end{tabular}

